\title{
Is there redundancy in bioengineering for molluscan assemblages on the rocky shores of central Chile?
}

\author{
¿Existe redundancia en la bioingeniería de los ensambles de moluscos \\ de las costas rocosas de Chile central?
}

BRENDAN P. KELAHER ${ }^{1}$, JUAN CARLOS CASTILLA $^{2, *} \&$ LUIS PRADO $^{3}$

\author{
${ }^{1}$ Institute for Water \& Environmental Resource Management and Department of Environmental Sciences, \\ University of Technology, Sydney, P.O. Box 123, Broadway, NSW, 2007, Australia \\ ${ }^{2}$ Centre for Advanced Study of Ecology \& Biodiversity, Facultad de Ciencias Biológicas, Pontificia Universidad Católica \\ de Chile, Casilla 114-D, Santiago, Chile \\ * E-mail for correspondence: jcastilla@bio.puc.cl
}

\begin{abstract}
Bioengineers modify habitats via their own physical structures and substantially increase local diversity in marine ecosystems. On rocky shores, there are large overlaps in the composition of communities associated with bioengineers that form complex mat-like habitats. We investigated the potential for redundancy in habitat provision by these types of habitats by comparing diverse molluscan assemblages associated with Perumytilus purpuratus mussel beds and algal turfs of Corallina officinalis var. chilenis, Gelidium chilense and Gastroclonium cylindricum. At three times between September 2003 and January 2004, we sampled the molluscan assemblages associated with each bioengineer at similar tidal heights on two rocky shores on the coast of central Chile. Of the 31 molluscan species identified, 30 were found in Corallina and 19-22 were identified from the other habitats. The pool of species found associated with each bioengineer overlapped greatly, demonstrating the potential for redundancy in habitat provision and little habitat-specificity. However, multivariate and univariate analyses showed all bioengineers except Gastroclonium contained a unique molluscan assemblage for at least one time of sampling because of variation in frequency of occurrence, richness and total abundance. Recent studies have highlighted many anthropogenic and natural processes that directly influence the diversity and composition of bioengineering species on rocky shores. We demonstrate that the loss of any particular bioengineer would not substantially alter the overall pool of molluscan species on the rocky shores of Chile. The loss of any bioengineer except Gastroclonium would, however, result in decreased local biodiversity because the molluscan assemblages in Perumytilus, Corallina and Gelidium, each contained a significantly different community structure for at least one time of sampling.
\end{abstract}

Key words: bioengineer, molluscs, redundancy, coralline turfs, mussels, rocky shores, Chile.

\section{RESUMEN}

En los ecosistemas marinos los organismos bioingenieros modifican hábitats a través de sus propias estructuras físicas e incrementan la diversidad local. En costas rocosas existen grandes solapamientos en la composición de las comunidades asociadas a bioingenieros que forman hábitats frondosos (algas) o mitílidos. Nosotros investigamos la potencial redundancia en la provisión de este tipo de hábitat comparando ensambles faunísticos asociados a mantos de Perumytilus purpuratus y frondas de Corallina officinalis var. chilenis, Gelidium chilense y Gastroclonium cylindricum. En tres oportunidades, entre septiembre de 2003 y enero de 2004, muestreamos ensambles de moluscos asociados a cada uno de estos bioingenieros, en alturas de mareas similares en dos áreas rocosas de Chile central. De las 31 especies de moluscos identificados, 30 fueron encontrados en Corallina y 19-22 fueron identificados en los otros hábitat. El conjunto de especies asociado a cada bioingeniero se sobrepone ampliamente, demostrando el potencial de redundancia en la provisión de hábitat y poca especificidad de hábitat. Sin embargo, análisis multivariados y univariados mostraron que los bioingenieros, con excepción de Gastroclonium, contenían un ensamble de moluscos único en al menos uno de los periodos de muestreo, ya sea en la variación en la frecuencia de ocurrencia, riqueza y abundancia total. Estudios recientes han destacado diversos procesos antropogénicos y naturales que influencian directamente la diversidad y composición de especies en bioingenieros de costas rocosas. Se demuestra que para la costa de Chile central la pérdida de cualquier de 
los bioingenieros analizados no alteraría sustancialmente el conjunto total de especies de moluscos, alojados en ellos. Sin embargo, la pérdida de cualquier bioingeniero, excepto Gastroclonium, resultaría en una disminución local de la biodiversidad debido a que cada uno de los ensambles de moluscos en Perumytilus, Corallina y Gelidium, contiene una estructura comunitaria significativamente diferente, en al menos uno de los periodos de muestreo.

Palabras clave: ingenieros ecosistémicos, moluscos, redundancia, algas coralinas, mitílidos, costas rocosas, Chile

\section{INTRODUCTION}

Species that substantially modify the environment via their own physical structure, such as kelps or corals, strongly influence local biodiversity and ecosystem performance (Jones et al. 1994, 1997, Bruno \& Bertness 2001). These marine bioengineers or habitat-forming species facilitate local biodiversity by providing a refuge from environmental stress (Seed 1996, Bulleri et al. 2002) and predation (Coull \& Wells 1983, Grabowski 2004), altering competitive interactions (Fletcher \& Underwood 1987, Bertness \& Callaway 1994), reducing the impacts of physical disturbance (Jones \& Syms 1998, Syms \& Jones 2000) and increasing local resources, such as food or space (Thompson et al. 1996, Kelaher et al. 2001).

The influence of bioengineers on marine community structure depends on how their biological and architectural characteristics create habitat space, alter abiotic resources or modulate environmental forces and biological processes (Jones et al. 1994, 1997). The physical characteristics of bioengineers often affect local biodiversity by creating more complex habitats that provide greater area for colonization (Connor \& Mccoy 1979, Thompson et al. 1996) and directly influence ecological processes and local conditions (see Bruno \& Bertness 2001, for a review see Jones et al. 1994). The biological characteristics of habit-forming species may also be strong determinants of associated community structure. Mussels, for example, not only provide a physical habitat for diverse communities of benthic invertebrates, but also detrital material for invertebrate consumption (Tsuchiya 1980, Seed 1996). On the other hand, they also prey on the larvae of settling organisms (Andre \& Rosenberg 1991, Wong et al. 2003). Other examples of biological characteristics of habitat-forming species that may influence community structure include exuding chemicals that attract or repel new settlers (Knight-Jones et al. 1975, Young 1990) or producing toxic substances that reduce recruitment, herbivory or predation (Hay et al. 1987, Borell et al. 2004) or even being themselves a food source (Navarrete \& Castilla 1988, Brawley 1992).

On rocky intertidal shores many bioengineers, such as mussels (Suchanek 1985, Seed 1996), ascidians (Cerda \& Castilla 2001, Monteiro et al. 2002) and algal turfs (Gee \& Warwick 1994, Kelaher et al. 2004), provide complex mat-like habitats for diverse invertebrate assemblages. These different bioengineering species often coexist in a mosaic of patches on the same shores (Connell 1972), providing opportunity for micro-habitat specialisation of associated fauna. Despite this, there is generally massive overlap in the composition of macrofaunal communities associated with different habitat-forming species in this system, although abundances and size-structures of individual populations may vary substantially (Myers \& Southgate 1980, Edgar 1991).

Similarity in the species assemblages associated with different bioengineers on rocky shores provides the potential for redundancy in habitat provision, as multiple ecosystem engineers can fulfil the same important ecological role (Walker 1992, Yachi \& Loreau 1999). Redundancy in biogenic habitat generation has important consequences for management of biodiversity of rocky shores, as a number of human activities strongly influence composition and dominance of important habitat forming species (Thompson et al. 2002). Shellfish gathering on African shores, for example, causes coralline algal turf to dominate space, rather than the naturally occurring mosaics of algal turfs and mussels (Dye 1992, Lasiak 1999). Alternatively, intertidal extraction of the predatory gastropod 
Concholepas concholepas (Brugière 1979) on Chilean shores causes spatial dominance of the mussel, Perumytilus purpuratus Lamarck 1819, which would normally be excluded by predation (Castilla \& Durán 1985, Castilla 1999). Furthermore, trampling by humans, on rocky shores may also influence the structure and composition of habitat-forming species (Keough \& Quinn 1998, Schiel \& Taylor 1999, Milazzo et al. 2004). For example, experimentally-simulated trampling on rocky shores in Australia reduced the abundance of coralline algal turf (Keough \& Quinn 1998), a habitat for hundreds of macrofaunal species (Kelaher et al. 2001).

We define redundancy in habitat provision to exist if two or more bioengineers are consistently associated with species assemblages that do not significantly differ. Nevertheless, how exactly differences in species assemblages should be tested has been an issue of some debate (Clarke 1993, Gray 2000, Anderson 2001). Perhaps the simplest way is the direct comparison of lists of species found associated with each bioengineer, although this method tends to overestimate the importance of rare species. Univariate measures of assemblage structure (species richness, species diversity, evenness, total abundance) also provide useful information about similarities or differences in species assemblages (Magurran 1988, Gray 2000), but tend not to focus on the identity of the species present. Comparisons among abundances or frequency of occurrence of individual species are informative, but do not consider correlations among the different species. Multivariate statistical methods can simultaneously incorporate many aspects of assemblage structure (Clarke 1993, Anderson 2001). However, the detail of exactly what is different is often lost in these gestalt measures. Given the vast array of choices for comparing assemblages the most robust test of redundancy in habitat provision would utilise a combination of the above approaches.

With growing concerns about conservation of marine biodiversity, there has been a recent emphasis on understanding the role that bioengineers play in enhancing local species diversity (Bruno \& Bertness 2001, Coleman \& Williams 2002, Crooks 2002). For rocky intertidal shores, however, it has been observed that there is major overlap over the composition of faunal communities associated with different bioengineers and therefore potential for redundancy in habitat provision. Here, we directly address this issue by describing tests of the hypothesis that if redundancy in bioengineering exists on rocky shores there will be no significant differences among molluscan assemblages associated with two or more major bioengineers on shores in central Chile. We employed a number of methods to test hypotheses about differences in molluscan assemblage structure among bioengineers, including comparisons of species lists, statistical tests for habitat specialisation of individual species and statistical comparisons of univariate and multivariate measures of assemblage structure.

\section{MATERIAL AND METHODS}

\section{Description of shores}

This study was undertaken on wave-exposed rocky shores of central Chile at Pichilemu

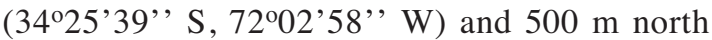
of the Marine Protected Area at Las Cruces (3330'10' ' S, 71'38'04', W). The structure of the intertidal communities on each shore were similar to those described for central Chile, in that they were dominated by beds of the mussel Perumytilus purpuratus in mid-shore areas and mats of algal turf, algal crusts and the large macroalgae Lessonia nigrescens Bory 1826 at lower tidal heights (Castilla 1981, Broitman et al. 2001). These shores also had obvious overlaps in the vertical distributions of mussel beds and several types of algal turfs. We focused on beds of Perumytilus and algal turfs of Gastroclonium cylindricum Santelices, Abbot \& Ramírez 1989, Gelidium chilense (Montagne) Santelices \& Montalva 1983 and Corallina officinalis var. chilensis (Decaisne) Kützing 1858 , because they often dominate the rocky shores of Central Chile (for full description of algal life histories see Hoffmann \& Santelices 1997). Each of these species formed a dense mat-like habitat that rarely exceeded $50 \mathrm{~mm}$ in height, although Gelidium fronds were on average longer at Pichilemu than at Las Cruces (for further quantitative description of structure characteristics of these 
species bioengineers see Kelaher \& Castilla 2005, Prado \& Castilla 2006, Wieters (2005). The mat-like structures created by these bioengineers altered local environmental conditions and provided habitat for diverse invertebrate assemblages (Kelaher \& Castilla 2005, Prado \& Castilla 2006, Wieters 2005)

\section{Sampling methods}

To test hypotheses about ecological redundancy among bioengineers, molluscan assemblages in the four habitat-forming species were sampled from a $20 \times 30 \mathrm{~m}$ area on both shores at three times (10-12 September 2003, 4-6 November 2003, and 2-8 January 2004). Multiple times and two shores were sampled to evaluate the generality of habitat redundancy. Although there are other taxa associated with these matlike and mussels bed habitats (i.e., Prado \& Castilla 2006), we focused on diverse molluscan assemblages because they are numerically dominant, encompass important functional groups and are well described. Each area was dominated by the four bioengineered habitats arranged in a complex mosaic of patches. In each area, five randomly-placed replicate cores were collected from each bioengineered habitat. The corer had an internal diameter of $80 \mathrm{~mm}\left(0.005 \mathrm{~m}^{2}\right)$, which provides relatively precise estimates of macrofaunal assemblages associated with these types of habitats (Kelaher 2001). To ensure commensurability, all cores were sampled from a similar tidal height $( \pm 0.2 \mathrm{~m})$ around mean low water of neap tides. This meant that cores of Perumytilus were taken from near the lower limit of its vertical distribution, whereas cores of Corallina, Gelidium and Gastroclonium were taken near their upper limit. The locations of cores were also deliberately interspersed throughout the sample area to avoid spatial confounding (Hurlbert 1984). Although juvenile Perumytilus were found in nearly every core collected, they were excluded from analyses because they defined one of the habitats investigated.

For each replicate core, all material contained within the corer was scraped to the level of the rock, placed in a plastic bag and taken to the laboratory. All replicates were washed in a $600 \mu \mathrm{m}$ sieve and preserved in $7 \%$ formalin solution. Any molluscs retained on the sieve were then sorted and identified under (x12) magnification.

\section{Data analysis}

Pooled species richness was estimated for each bioengineer by rarefying data with Coleman's rarefaction index (Colwell 1997). The samplebased rarefactions were plotted against the number of individuals to account for variation in abundance (Gotelli \& Colwell 2001). Nonrandom patterns of occurrence in molluscan species were tested using $\chi^{2}$ contingency tests for species that occurred in more than seven out of 120 cores, the minimum number of cores required for detecting a non-random pattern of distribution with four habitats. For all other analyses, the entire data set (rare and common species were included). Non-parametric multivariate analysis of variance (NPMANOVA) was used to test hypotheses about differences in molluscan assemblages associated with the different bioengineers (Anderson 2001, Mcardle \& Anderson 2001) and non-metric multidimensional scaling (nMDS, Field et al. 1982) was used to produce two-dimensional ordination plots that graphically show these relationships. All multivariate analyses were carried out using untransformed data and Bray-Curtis similarity coefficients (Bray \& Curtis 1957). The data were not transformed because for these mollusc assemblages the abundant species are more likely to have a greater influence on the ecology of the system than the rare species and there were on average less than 100 individual molluscs per core.

Analysis of variance (ANOVA) was used to compare univariate measures of assemblage structure i.e., species richness, total abundance and assemblage evenness J' (Pielou 1975). Where appropriate, SNK tests were used for $a$ posteriori comparisons among means. To better satisfy assumptions of ANOVA, raw abundances were transformed to $\operatorname{Ln}(x+1)$ prior to analysis (Underwood 1997). Because shores and sampling times were random effects, there was no exact F-test to compare among habitats in the three-factor analyses. When such a test was necessary, an F-ratio was estimated by eliminating a non-significant interaction term (at $\mathrm{P}>0.30$ ) from the model (Underwood 1997). 


\section{RESULTS}

\section{Patterns of richness and occurrence}

In total, 31 species of molluscs were found in the four habitat-forming species (Table 1). Thirty of these species were found in Corallina, which was greater than the 22,19 and 20 molluscan species identified from Gastroclonium, Gelidium and Perumytilus, respectively. Despite this, the total number of species found did not vary significantly among bioengineers $\left(\chi^{2}=1.22,3\right.$ d.f., $\left.\mathrm{P}>0.05\right)$. With the exception of a single juvenile Crepidula, the molluscan species found in Gastroclonium, Gelidium and Perumytilus were a subset of those associated with Corallina. The four species that were found exclusively in Corallina were all rare, occurring in one core only.

TABLE 1

Number of cores (samples) in which each molluscan species was found for each of the four bioengineered habitats

Número de muestras en las cuales cada especie de molusco fue encontrado en cada uno de los bioingenieros

\begin{tabular}{|c|c|c|c|c|c|}
\hline Class & Species & Corallina & Gastroclonium & Gelidium & Perumytilus \\
\hline \multirow[t]{4}{*}{ Polyplacophora } & Chaetopleura benaventei ${ }^{\S}$ & 1 & 0 & 1 & 0 \\
\hline & Chiton barnesi & 3 & 3 & 0 & 1 \\
\hline & Chiton granosust & 3 & 3 & 6 & 24 \\
\hline & Tonicia sp§ & 4 & 0 & 0 & 2 \\
\hline \multirow[t]{19}{*}{ Gastropoda } & Acanthina monodon§ & 3 & 1 & 1 & 0 \\
\hline & Concholepas concholepas & 2 & 0 & 0 & 2 \\
\hline & Crepidula sp§ & 0 & 0 & 0 & 1 \\
\hline & Eatoniella glomerosa & 6 & 5 & 11 & 0 \\
\hline & Eatoniella nigra§ & 2 & 2 & 0 & 1 \\
\hline & Fissurella spp $\dagger$ & 9 & 13 & 11 & 9 \\
\hline & Flabellina sp§ & 1 & 0 & 0 & 0 \\
\hline & Littorina araucana & 2 & 1 & 3 & 2 \\
\hline & Marinula sp§ & 1 & 0 & 0 & 0 \\
\hline & Mitrella unifasciata & 8 & 1 & 1 & 1 \\
\hline & Prissogaster elevatus & 1 & 0 & 0 & 0 \\
\hline & Prissogaster niger§ & 1 & 1 & 0 & 0 \\
\hline & Scurria araucana & 1 & 1 & 5 & 6 \\
\hline & Scurria ceciliana & 14 & 24 & 23 & 29 \\
\hline & Scurria variabilisł & 1 & 1 & 2 & 17 \\
\hline & Siphonaria lessoni & 1 & 4 & 5 & 18 \\
\hline & Tegula atra $\ddagger$ & 25 & 18 & 8 & 6 \\
\hline & Tricolia macleani§ & 1 & 0 & 0 & 0 \\
\hline & Tricolia umbilicata & 8 & 4 & 3 & 3 \\
\hline \multirow[t]{8}{*}{ Bivalvia } & Aulacomya atra & 3 & 1 & 1 & 2 \\
\hline & Brachidontes granulata & 29 & 30 & 28 & 23 \\
\hline & Cyclinella kroyeri§ & 1 & 1 & 0 & 0 \\
\hline & Entodesma cuneata & 5 & 2 & 1 & 1 \\
\hline & Hiatella solida§ & 1 & 0 & 0 & 0 \\
\hline & Lasaea petitiana & 2 & 5 & 5 & 1 \\
\hline & Petricola rugosa§ & 2 & 2 & 1 & 0 \\
\hline & Semimytilus algosus $\ddagger$ & 28 & 18 & 23 & 7 \\
\hline Totals & 31 & 30 & 22 & 19 & 20 \\
\hline
\end{tabular}

\$Species that occurred in less than seven cores, which was considered the minimum number of occurrences required to show a significant non-random pattern with four habitats. ${ }^{+}$Species that showed a significant non-random pattern in occurrence among habitats $\left(\chi^{2}>7.81,3\right.$ d.f., $\left.\mathrm{P}<0.05\right)$. ${ }^{\dagger}$ It was not possible to reliably separate all juvenile fissurelids to species level. To be conservative, genus level was used for this particular group.

$\S$ Especies que fueron encontradas en menos de siete muestras, que se consideró el número mínimo de ocurrencia requerido para mostrar un patrón no aleatorio significativo para cuatro hábitat. ‡Especies que mostraron un patrón de ocurrencia no aleatorio significativo entre hábitats $\left(\chi^{2}>7,81 ; 3\right.$ d.f., $\left.\mathrm{P}<0,05\right)$. No fue posible separar fidedignamente todos los fissurélidos juveniles hasta el nivel de especie. Para ser conservativo, el nivel taxonómico de género fue utilizado para este grupo en particular. 
Fourteen of the total 31 species occurred in less than seven of the 120 cores (Table 1). All the remaining species were found in each habitat except for Chiton barnesi Gray 1847 , which did not occur in Gelidium, and the microgastropod Eatoniella glomerosa Ponder and Worsfold 1994, which was not found in Perumytilus. The absence of these species could, however, be explained by chance alone $\left(\chi^{2}<7.81,3\right.$ d.f., $\left.\mathrm{P}>0.05\right)$.

Five species showed a significant nonrandom pattern in their frequency of occurrence (Table 1). Juveniles of Chiton granosus Frembly 1827 and limpets Scurria variabilis (Sowerby 1839) and Siphonaria lessoni (Blainville 1824) were found in greater than three times as many cores of Perumytilus than in the other habitats. In contrast, juveniles of the mussel Semimytilus algosus (Gould 1850) occurred in fewer than half as many cores of Perumytilus as in the other habitats. Juvenile Tegula atra (Lesson 1830) were found in twice as many cores of Corallina and Gastroclonium than in the other two bioengineered habitats.
Molluscan richness in coralline turf was ca. $40 \%$ greater than the other habitats for a similar number of individuals, despite Corallina only having ca. $35 \%$ less individuals than the others (Fig. 1). The species-individual curves for Gastroclonium, Gelidium and Perumytilus followed a similar trend, except where there were ca. 200 fewer molluscs found in the Gelidium samples.

\section{Variation in molluscan assemblages}

Molluscan assemblages varied significantly among bioengineered habitats, although the direction and magnitude of these differences changed significantly through time (see $\mathrm{H}$ x $\mathrm{T}$ interaction, Table 2A, Fig. 2). The patterns of difference in molluscan assemblages among habitats appeared to be relatively consistent between shores (see non-significant $\mathrm{H}$ x $\mathrm{T}$ x S and $\mathrm{H} \times \mathrm{S}$ interactions Table 2A, Fig. 2). However, more replicates would be needed to conclusively support this finding, as interactions terms were only marginally nonsignificant and post-hoc tests highlighted some potential inconsistencies (Table 2A, Fig. 2).

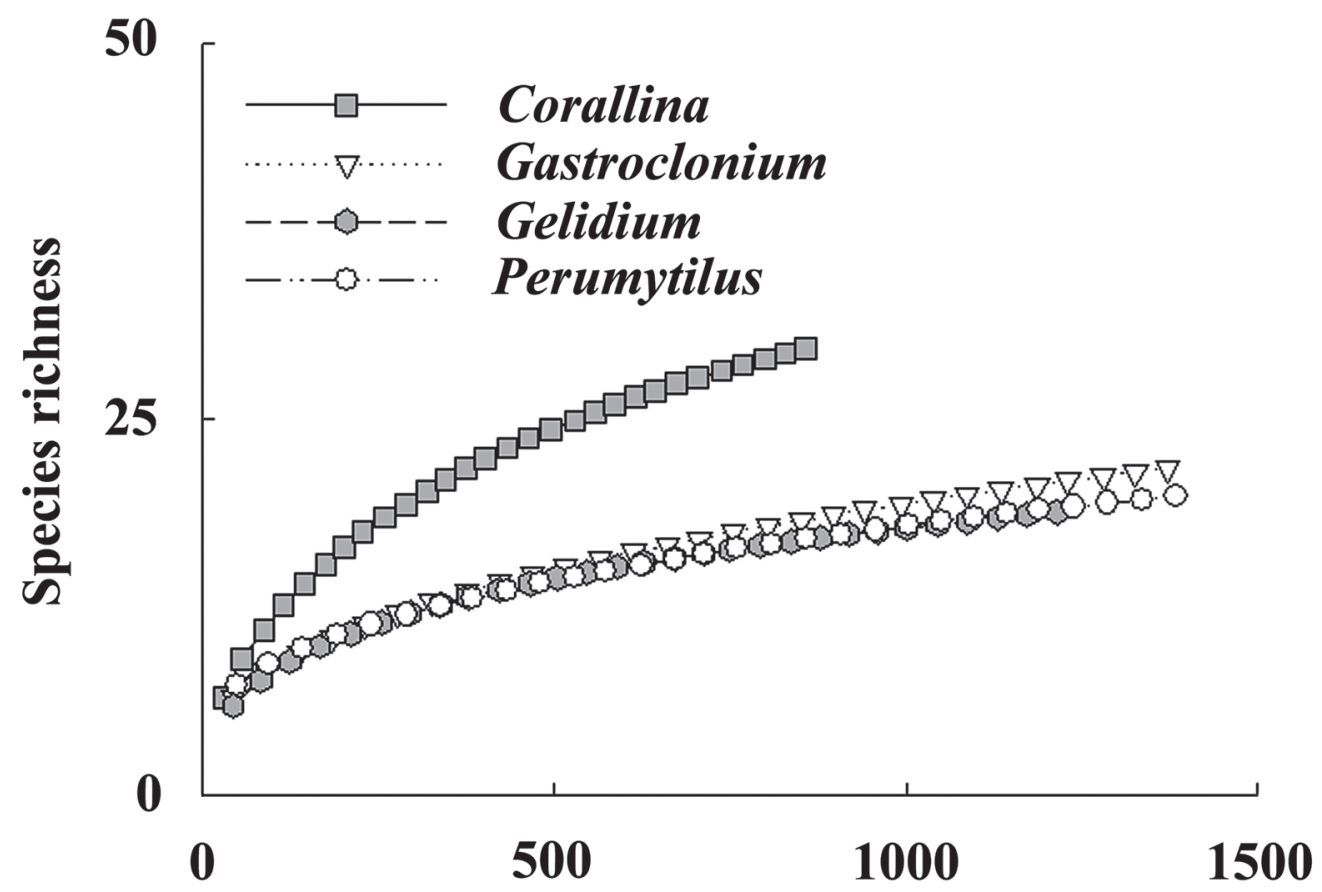

Fig. 1: Coleman rarefaction curves for each bioengineered habitat generated by pooling replicate cores across times and shores.

Curvas de rarefacción de Coleman para cada hábitat bioingeniero mezclando todas las réplicas a lo largo de tiempos y costas. 
TABLE 2

NP-MANOVA and ANOVAs comparing molluscan assemblages among the four bioengineered habitats from Las Cruces and Pichilemu at three times of sampling. ${ }^{\S}$ Data transformed with Ln $(\mathrm{x}+1)$.*Non-significant interaction eliminated to generate an F-test for habitats. *F-ratio not estimated because of significant interactions; p-F denotes pseudo F-values

NP-MANDEVA y ANDEVAs comparando los ensambles de moluscos entre los cuatro hábitats bioingenieros de Las Cruces y Pichilemu en los tres tiempos de muestreo. ${ }^{\S}$ Datos transformados con Ln $(\mathrm{x}+1)$. *Interacciones no significativas eliminadas para generar una prueba de $\mathrm{F}$ para hábitat. ${ }^{\ddagger} \mathrm{F}$ no estimado debido a interacciones significativas; $\mathrm{p}$ - $\mathrm{F}$ indica una prueba no exacta de F (pseudo valores de F)

\begin{tabular}{|c|c|c|c|c|c|c|c|}
\hline \multirow[t]{2}{*}{ Source of variation } & \multirow[b]{2}{*}{$\mathrm{df}$} & \multicolumn{3}{|c|}{ (a) Entire assemblage } & \multicolumn{3}{|c|}{ (b) Species richness } \\
\hline & & MS & $\mathrm{p}-\mathrm{F}$ & P-value & MS & F-value & P-value \\
\hline Habitat $=\mathrm{H}$ & 3 & 2.69 & $\ddagger$ & & 6.59 & $\ddagger$ & \\
\hline Time of sampling $=\mathrm{T}$ & 2 & 0.47 & 1.43 & 0.34 & 8.91 & 356.33 & $<0.01$ \\
\hline Shore $=S$ & 1 & 1.56 & 4.73 & $<0.05$ & 9.08 & 363.00 & $<0.01$ \\
\hline $\mathrm{H} \times \mathrm{T}$ & 6 & 0.56 & 2.72 & $<0.01$ & 3.85 & 0.45 & 0.82 \\
\hline $\mathrm{H} \times \mathrm{S}$ & 3 & 0.38 & 1.86 & 0.06 & 3.1 & 0.36 & 0.78 \\
\hline $\mathrm{T} \times \mathrm{S}$ & 2 & 0.33 & 2.17 & $<0.05$ & 0.03 & 0.01 & 0.99 \\
\hline $\mathrm{H} \times \mathrm{T} \times \mathrm{S}$ & 6 & 0.21 & 1.36 & 0.10 & 8.55 & 3.90 & $<0.05$ \\
\hline Residual & 96 & 0.15 & & & 2.19 & & \\
\hline \multirow[t]{2}{*}{ Source of variation } & & \multicolumn{3}{|c|}{ (c) Total abundance $\S$} & \multicolumn{3}{|c|}{ (d) Evenness } \\
\hline & df & MS & F-value & P-value & MS & F-value & P-value \\
\hline Habitat $=\mathrm{H}$ & 3 & 1.81 & $\ddagger$ & & 0.07 & 3.13 & 0.11 \\
\hline Time of sampling $=\mathrm{T}$ & 2 & 3.01 & 2.77 & 0.27 & 0.02 & 0.55 & 0.64 \\
\hline Shore $=\mathrm{S}$ & 1 & 1.52 & 1.40 & 0.36 & 0.01 & 0.18 & 0.71 \\
\hline $\mathrm{H} \times \mathrm{T}$ & 6 & 0.88 & 1.09 & 0.46 & 0.02 & 1.06 & 0.47 \\
\hline $\mathrm{H} \times \mathrm{S}$ & 3 & 1.28 & 1.58 & 0.29 & $* 0.01$ & $* 0.46$ & $* 0.72$ \\
\hline $\mathrm{T} \times \mathrm{S}$ & 2 & 1.09 & 3.03 & $<0.05$ & 0.04 & 1.64 & 0.20 \\
\hline $\mathrm{H} \times \mathrm{T} \times \mathrm{S}$ & 6 & 0.81 & 2.25 & $<0.05$ & 0.02 & 0.94 & 0.47 \\
\hline Residual & 96 & 0.36 & & & 0.02 & & \\
\hline
\end{tabular}

In September 2003 and January 2004, multivariate analyses demonstrated that molluscan assemblages in Perumytilus were significantly different from those in the other bioengineers (Fig. 2). For each time of sampling, between 85 and $93 \%$ of the total dissimilarity between molluscs in Perumytilus and the other habitats was explained by just seven species: the limpets Scurria ceciliana (Orbignyi 1841), Scurria variabilis and Siphonaria lessoni; the mussels Brachidontes granulata (Hanley 1843) and Semimytilus algosus; the trochid gastropod Tegula atra and Chiton granosus. In particular, Scurria ceciliana (17-54\%) and Brachidontes granulata (9-38 \%) had consistently large contributions to the total dissimilarity for all comparisons between Perumytilus and algal turfs on each shore and at each time of sampling.

In September and November 2003, molluscan assemblages associated with the different algal turfs did not differ significantly, apart from those in Gelidium at Las Cruces for the first time of sampling (Fig. 2). In January 2004, however, assemblages in Corallina differed significantly from those in Gelidium and Gastroclonium. This difference was mostly caused by a decrease in the abundance of molluscs in Corallina relative to the other bioengineers, especially in abundant species such as Brachidontes granulata and Scurria ceciliana. 

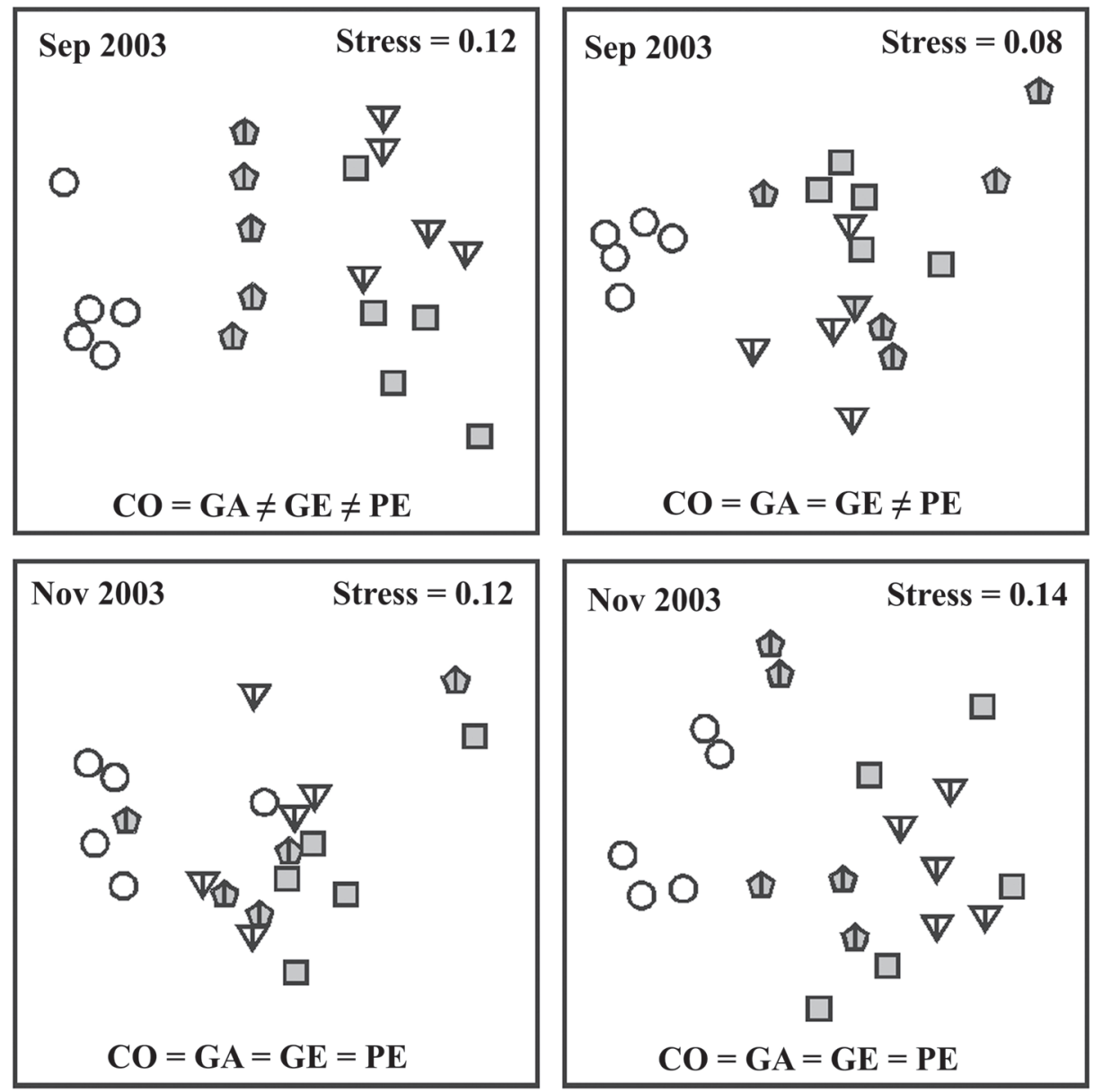

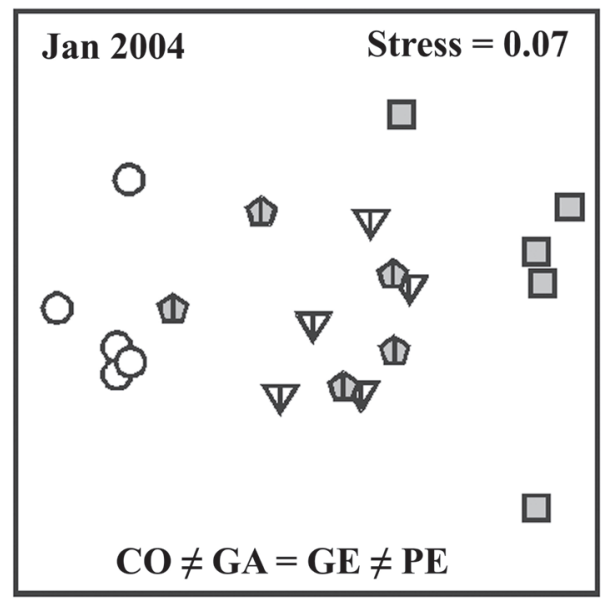

Las Cruces

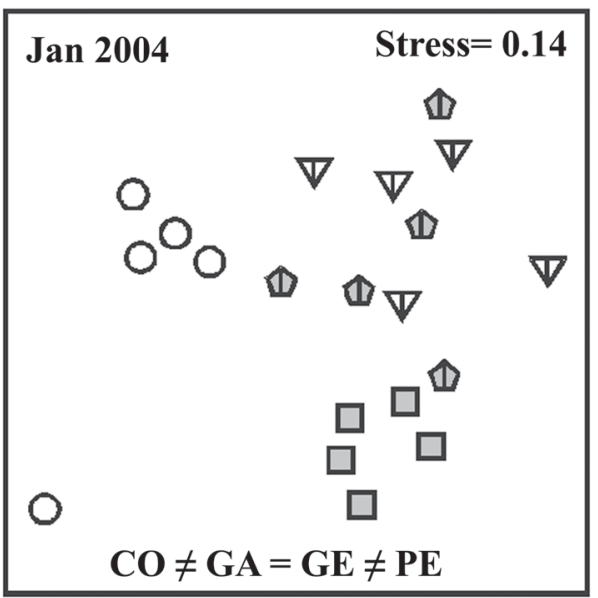

Pichilemu

Fig. 2: Two-dimensional nMDS ordination ( $\mathrm{n}=5$ cores) comparing molluscan assemblages associated with Corallina (CO, $\square$ ), Gastroclonium (GA, $\boldsymbol{\nabla})$, Gelidium (GE, $\mathbb{\Phi}$ ) and Perumytilus $(\mathrm{PE}, \mathrm{O})$ from Las Cruces and Pichilemu at the three times of sampling. Results of NP-MANOVA pair-wise comparisons are indicated with "=" $(\mathrm{P}>0.05)$ and " $\neq$ " $(\mathrm{P}<0.05)$.

Ordenación bi-dimensional ( $\mathrm{n}=5$ réplicas) comparando ensambles de moluscos asociados con Corallina (CO, $\square$ ), Gastroclonium $(\mathrm{GA}, \boldsymbol{\nabla})$, Gelidium $(\mathrm{GE}, \mathbb{\Phi})$ y Perumytilus (PE, O) de Las Cruces y Pichilemu en los tres tiempos de muestreo. Los resultados de las comparaciones pareadas de NP-MANDEVA se indican con "=" $(P>0,05)$ y " $\neq$ " $(P<0,05)$. 
There were no consistent patterns of difference in univariate assemblage measures among the different bioengineered habitats (Fig. 3). For example, variation in the richness of species (per core) among habitats at Las Cruces in November 2003 was caused by there being fewer species in Gastroclonium than in the other habitats. However, the exact opposite pattern was shown in January 2004 with the greatest number of species being found in Gastroclonium (see $\mathrm{H} \times \mathrm{S} \times \mathrm{T}$ interaction in Table 2B, Fig. 3). Similarly, variation in total abundance of individuals among habitats at Pichilemu was equally inconsistent (see $\mathrm{H}$ x S $\mathrm{x}$ T interaction in Table 2C, Fig. 2). Significant variation in September 2003 at Pichilemu was caused by greater numbers of molluscs associated with Gastroclonium than in the other habitats, whereas significant variation in January 2004 was caused by fewer molluscs in coralline turf than the other habitats (Fig. 3). Finally, the evenness of assemblages did not vary significantly among habitats, shores or times of sampling (Table 2D, Fig. 3).

\section{DISCUSSION}

There was major overlap in the suite of molluscan species found associated with the four different bioengineers and, therefore, potential for redundancy in habitat provision (Walker 1992, Bruno \& Bertness 2001). However, some caution needs to be taken in interpreting these results. First, the full vertical range of each bioengineer was not sampled because cores were deliberately taken from the same tidal height. Therefore, it is possible that species assemblages associated with each bioengineer at different tidal heights differ from those presented, especially mussels which extended further up the shore than the algal turfs. However, more extensive sampling of mussel beds (Prado \& Castilla 2006) and coralline turf (Kelaher \& Castilla 2005) reveals that our samples included virtually all the molluscs likely to be encountered in these habitats. Second, it is unlikely that absolutely every species of mollusc was sampled from each bioengineer as rarefaction curves were not fully asymptotic and not every season was sampled. Once again, more extensive sampling of mussels and coralline turf demonstrates that our data included all but the rarest molluscan species (see Kelaher et al. 2004, Kelaher \& Castilla 2005, Prado \& Castilla 2006) and in most cases these rare species were vagrants found commonly in other habitats (i.e., on open rock areas, amongst barnacles). Although very rare species are an important component of benthic assemblages, they have little bearing on hypotheses tested statistically here, as they only have a minor contribution to multivariate analyses, are not common enough to have a major influence on species richness or to be assigned to a particular bioengineer more than can be expected by chance (see methods).

The extent of habitat redundancy for molluscan species depended entirely on the definition of biodiversity employed. If the decision was based on the list of species found associated with each bioengineer, the loss of any one of these habitat-forming species apart from Corallina would have little influence on molluscan diversity. If, however, the definition of biodiversity was more inclusive, such as multivariate assemblage structure (which among other things includes number of species, identity of species, frequency of species occurrence and abundances of individual populations), the loss of mussels would represent a reduction in biodiversity because the molluscan assemblages found associated with this bioengineer differed significantly from the others. Similarly, for at least one sampling time the molluscan assemblages found in Corallina and Gelidium were also significantly different from the others. Thus loss of either of these bioengineers would also represent a reduction in molluscan biodiversity. The only bioengineer that was potentially redundant on the rocky shores of Chile was Gastroclonium because there were no species of mollusc unique to this habitat and its molluscan assemblage structure was never significantly different from one or more of the other habitat-forming species.

While habitat specialization is prevalent in many aquatic and terrestrial ecosystems, we found virtually no evidence for molluscs demonstrating strict habitat-specificity with any particular bioengineer as the few molluscan species found in one habitat only occurred in one out of the 120 cores, which could well be by chance alone. A number of mollusc species were, however, found in some habitats more 
than expected by chance. These species can be roughly divided into two categories: (i) those that occurred more frequently in mussels beds, such as scurrid limpets and (ii) those that were more commonly found in algal turfs, such a trochid gastropods or mussels other than Perumytilus. For the mobile species, there is experimental evidence that molluscs associated with mat-like bioengineers show strong behavioral preferences for particular microhabitats (Olabarria et al. 2002). There are, however, other potential explanations relating to differential survival or larval settlement rates, which may be more important to the sessile molluscs showing non-random patterns of occurrence, such as Semimytilus algosus.
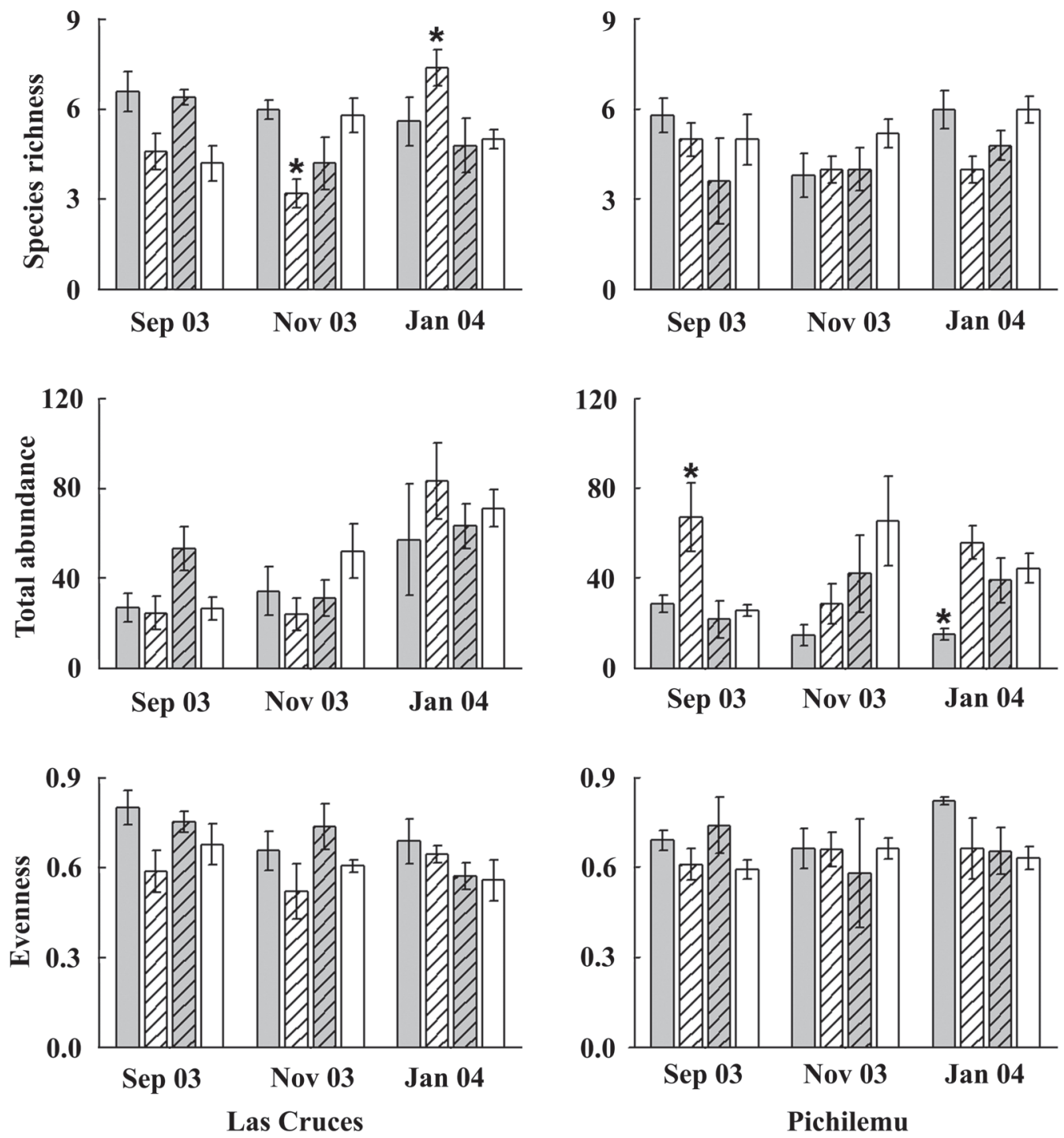

Fig. 3: Mean $( \pm \mathrm{SE}, \mathrm{n}=5$ cores $)$ value of univariate assemblage measures comparing molluscan assemblages associated with Corallina ( $\square$ ), Gastroclonium ( RZZ), Gelidium ( ZZZ) and Perumytilus ( $\square$ ) from Las Cruces and Pichilemu at the three times of sampling; * above bars indicates that a particular habitat was significantly different from the others $(\mathrm{SNK}, \mathrm{P}<0.05)$.

Valor promedio $( \pm \mathrm{EE}, \mathrm{n}=5$ muestras) de las medidas univariadas comparando ensambles de moluscos asociados a

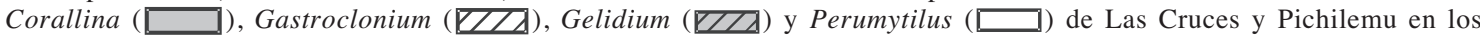
tres tiempos de muestreo; * sobre las barras indica que un hábitat particular fue significativamente diferente de los otros $(\mathrm{SNK}, \mathrm{P}<0,05)$. 
Given the high value placed on the bioengineering capabilities of mussels (Suchanek 1985, Seed 1996, Bruno et al. 2003), it was somewhat unexpected that this bioengineer did not have significantly more molluscs than the other habitat-forming species. A number of generalizations have been founded on this perception of mussel beds, such as a basis for criticism of keystone predation on the shores of Washington State, USA. Paine's (1969, 1974) classic experiments showed that the diversity of species occupying primary substratum was reduced to a monoculture of the mussels Mytilus californianus (Conrad 1837) if the predatory seastar Pisaster ochraceus Brand 1835 was experimentally excluded. Nevertheless, because the mussel beds in this area provide habitat for many infaunal species (Suchanek 1980, 1994), as well as surfaces for all the primary substrate holders (Lohse 1993), it has been assumed that there must have been many more species in areas dominated by mussels than found in the unmanipulated plots. It is now often concluded that seastar predation actually causes a decrease in overall species richness (Lohse 1993, Tokeshi \& Romero 1995, Mckindsey \& Bourget 2001, Bruno et al. 2003). What has been overlooked, however, is that coralline algal turf particularly benefited from seastar predation occupying ca. $20 \%$ of Paine's unmanipulated plots. Because coralline turf provides habitat for many of the molluscs found in mussel beds, differences in overall molluscan species richness are probably not nearly as large as previously thought. While some consideration needs to be given to the exceptional mussel beds in Paine's study sites (e.g., up to six mussel layers, about $30 \mathrm{~cm}$ thick Suchanek 1985), this is one situation where redundancy in bioengineering probably plays an important role in modulating supposed changes in biodiversity.

Redundancy in bioengineering also has important implications for the management of biodiversity on rocky shores. Extraction of the mussel, Perna perna (Linnaeus 1758), on the eastern coast of South Africa, for example, changes rocky shore communities from a mosaic of coralline algal turf, mussel beds and bare rock areas to be dominated by mats of coralline algal turf (Dye 1992, 1993). While such impacts have little effect on the overall number of species associated with bioengineers, abundances of particular species, the frequency in which they occur probably differs greatly between the algal turf and mussel beds (Lasiak \& Field 1995, Lasiak 1999). The loss of mussels due to human harvesting, therefore, probably causes a decrease in local biodiversity because the specific assemblage structure associated with mussel beds is lost (Lasiak 1999). In contrast, extraction of the predatory gastropod Concholepas concholepas by humans in Chile allows the formation of dense mussel beds (Castilla \& Durán 1985, Castilla 1999), although patches of algal turf are still common (Santelices 1989). On shores where intertidal extraction is prohibited there are large areas of bare rock dominated by barnacles or algal crusts, many fewer mussels and a similar cover of turfing algae. In this situation, harvesting Concholepas probably has little influence on the overall richness of molluscs associated with mat-like habitats, but increases the dominance of molluscan communities specific to Perumytilus beds.

Amid concerns about loss of marine biodiversity, there is clear need to understand the role of ecosystem engineering in coastal ecosystems (Bruno \& Bertness 2001, Coleman \& Williams 2002, Crooks 2002). While past attention has focused on the important role of a few key bioengineers such as mussel beds, we show that on rocky shores many habitatforming species support diverse molluscan assemblages comprised of similar species and that there is virtually no evidence for habitatspecificity (i.e., molluscan species were rarely only associated with a particular habitat). Despite this, 3 out of 4 bioengineers investigated were associated with a significantly different molluscan assemblage for at least one time of sampling. In most cases, therefore, anthropogenic or natural processes that cause the loss of a particular bioengineer will result in a net loss of molluscan biodiversity because the composition of these species and the frequency with which they occur is relatively unique to each bioengineer. Nevertheless, to sustain this conclusion further studies, for instance, regarding the spatial and temporal pattern of recruitment of studied mollusc are needed. 


\section{ACKNOWLEDGMENTS}

This study was supported by funds from the Centre for Advanced Studies of Ecology \& Biodiversity (FONDAP), Project 15001-0001, Pontificia Universidad Católica de Chile. We would like to thank Dr. Theresa Dye and Dr. Melanie Bishop for comments on an earlier draft of this manuscript.

\section{LITERATURE CITED}

ANDERSON MJ (2001) A new method for non-parametric multivariate analysis of variance in ecology. Austral Ecology 26: 32-46.

ANDRE C \& R ROSENBERG (1991) Adult-larval interactions in the suspension-feeding bivalves Cerastoderma edule and Mya arenaria. Marine Ecology Progress Series 71: 227-234.

BERTNESS MD \& R CALLAWAY (1994) Positive interactions in communities. Trends in Ecology \& Evolution 9: 191-193.

BORELL EM, A FOGGO \& R COLEMAN (2004) Induced resistance in intertidal macroalgae modifies feeding behavior of herbivorous snails. Oecologia 140: 328334.

BRAWLEY S (1992) Mesoherbivores. In: Hawkins S \& Price J (eds) Plant-animal interactions in the marine benthos: 235-263. Oxford University Press, New York, USA.

BRAY J \& J CURTIS (1957) An ordination of the upland forest communities of southern Wisconsin. Ecological Monographs 27: 325-349.

BROITMAN B, S NAVARRETE S, F SMITH \& S GAINES (2001) Geographic variation of southeastern Pacific intertidal communities. Marine Ecology Progress Series 224: 21-34.

BRUNO J \& M BERTNESS (2001) Habitat modification and facilitation in benthic marine communities. In: Bertness M, M Hay \& S Gaines (eds) Marine community ecology: 201-218. Sinauer, Sunderland, Massachusetts, USA.

BRUNO J, J STACHOWICZ \& M BERTNESS (2003) Inclusion of facilitation into ecological theory. Trends in Ecology \& Evolution 18: 119-125.

BULLERI F, L BENEDETTI-CECCHI, S ACUNTO, F CINELLI \& S HAWKINS (2002) The influence of canopy algae on vertical patterns of distribution of low-shore assemblages on rocky coasts in the northwest Mediterranean. Journal of Experimental Marine Biology and Ecology 267: 89-106.

CASTILLA J (1981) Perspectivas de investigación en estructura y dinámica de comunidades intermareales rocosas de Chile central. II. Depredadores de alto nivel trófico. Medio Ambiente (Chile) 5: 190-215.

CASTILLA J (1999) Coastal marine communities: trends and perspectives from human- exclusion experiments. Trends in Ecology \& Evolution 14: 280-283.

CASTILLA J \& L DURÁN (1985) Human exclusion from the rocky intertidal zone of central Chile: the effects of Concholepas concholepas (Gastropoda). Oikos 45: 391-399.

CERDA M \& J CASTILLA (2001) Diversity and biomass of macroinvertebrates in intertidal matrices of the tunicate Pyura praeputialis (Heller, 1878) in the Bay of Antofagasta, Chile. Revista Chilena de Historia Natural 74: 841-853.

CLARKE K (1993) Non-parametric analyses of changes in community structure. Australian Journal of Ecology 18: 117-143.

COLEMAN F \& S WILLIAMS (2002) Overexploiting marine ecosystem engineers: potential consequences for biodiversity. Trends in Ecology \& Evolution 17: 40-44.

COLWELL R (1997) EstimateS: statistical estimation of species richness and shared species from samples. http://viceroy.eeb.uconn.edu/estimates.

CONNELL J (1972) Community interactions on marine rocky intertidal shores. Annual Review of Ecology and Systematics 3: 169-192.

CONNOR E \& E MCCOY (1979) The statistics and biology of the species-area relationship. American Naturalist 113: 791-833.

COULL B \& J WELLS (1983) Refuges from fish predation: experiments with phytal meiofauna from the New Zealand rocky intertidal. Ecology 64: 1599-1609.

CROOKS J (2002) Characterizing ecosystem-level consequences of biological invasions: the role of ecosystem engineers. Oikos 97: 153-166.

DYE A (1992) Experimental studies of succession and stability in rocky intertidal communities subject to artisan shellfish gathering. Netherlands Journal of Sea Research 30: 209-217.

DYE A (1993) Recolonization of intertidal macroalgae in relation to gap size and molluscan herbivory on a rocky shore on the east coast of southern Africa. Marine Ecology Progress Series 95: 263-271.

EDGAR G (1991) Artificial algae as habitat for mobile epifauna: factors affecting colonization in a Japanese Sargassum bed. Hydrobiologia 226: 111118.

FIELD J, K CLARKE \& R WARWICK (1982) A practical strategy for analyzing multispecies distribution patterns. Marine Ecology Progress Series 8: 37-52.

FLETCHER W \& A UNDERWOOD (1987) Interspecific competition among subtidal limpets: effect of substratum heterogeneity. Ecology 68: 387-400.

GEE J \& R WARWICK (1994) Metazoan community structure in relation to the fractal dimensions of marine macroalgae. Marine Ecology Progress Series 103: $141-150$

GOTELLI N \& R COLWELL (2001) Quantifying biodiversity: procedures and pitfalls in the measurement and comparison of species richness. Ecology Letters 4: 379-391.

GRABOWSKI J (2004) Habitat complexity disrupts predator-prey interactions but not the trophic cascade on oyster reefs. Ecology 85: 995-1004.

GRAY J (2000) The measurement of marine species diversity, with an application to the benthic fauna of the Norwegian continental shelf. Journal of Experimental Marine Biology and Ecology 250: 23-49.

HAY M, J DUFFY \& C PFISTER (1987) Chemical defense against different marine herbivores: are amphipods insect equivalents. Ecology 68: 15671580 .

HOFFMANN A \& B SANTELICES (1997) Flora marina de Chile central. Ediciones Pontificia Universidad Católica de Chile, Santiago, Chile. 434 pp

HURLBERT S (1984) Pseudoreplication and the design of ecological field experiments. Ecological Monographs 54: 187-211. 
JONES C, J LAWTON \& M SHACHAK (1994) Organisms as ecosystem engineers. Oikos 69: 373386.

JONES C, J LAWTON \& M SHACHAK (1997) Positive and negative effects of organisms as physical ecosystem engineers. Ecology 78: 1946-1957.

JONES G \& C SYMS (1998) Disturbance, habitat structure and the ecology of fishes on coral reefs. Australian Journal of Ecology 23: 287-297.

KELAHER B (2001) Biodiversity of macrofaunal assemblages in coralline algal turf. $\mathrm{Ph}$. D. thesis, University of Sydney, Sydney, Australia. 215 pp

KELAHER B \& J CASTILLA (2005) Habitat characteristics influence macrofauna richness in coralline turf more than mesoscale coastal upwelling on the coast of northern Chile. Estuarine Coastal and Shelf Science 63: 155-165.

KELAHER B ，J CASTILLA \& R SEED (2004) Intercontinental test of generality for spatial patterns among diverse molluscan assemblages in coralline algal turf. Marine Ecology Progress Series 271: 221-231.

KELAHER B, M CHAPMAN \& A UNDERWOOD (2001) Spatial patterns of diverse macrofaunal assemblages in coralline turf and their association with environmental variables. Journal of the Marine Biological Association of the United Kingdom 81: 1-14.

KEOUGH M \& G QUINN (1998) Effects of periodic disturbances from trampling on rocky intertidal algal beds. Ecological Applications 8: 141-161.

KNIGHT-JONES E, P KNIGHT-JONES \& S AL-OGILY (1975) Ecological isolation in the Spirobidae. In: editors names (eds) chapter title: 539-561. Editorial name, city, country.

LASIAK T (1999) The putative impact of exploitation on rocky infratidal macrofaunal assemblages: a multiple-area comparison. Journal of the Marine Biological Association of the United Kingdom 79: 23-34.

LASIAK T \& J FIELD (1995) Community-level attributes of exploited and non-exploited rocky infratidal macrofaunal assemblages in Transkei. Journal of Experimental Marine Biology and Ecology 185: 3353.

LOHSE D (1993) The importance of secondary substratum in a rocky intertidal community. Journal of Experimental Marine Biology and Ecology 166: 117.

MAGURRAN A (1988) Ecological diversity and its measurement. Princeton University Press, Princeton, New Jersey, USA. 175 pp.

MCARDLE B \& M ANDERSON (2001) Fitting multivariate models to community data: a comment on distance-based redundancy analysis. Ecology 82: 290-297.

MCKINDSEY C \& E BOURGET (2001) Diversity of a northern rocky intertidal community: the influence of body size and succession. Ecology 82: 34623478 .

MILAZZO M, F BADALAMENTI, S RIGGIO \& R CHEMELLO (2004) Patterns of algal recovery and small-scale effects of canopy removal as a result of human trampling on a Mediterranean rocky shallow community. Biological Conservation 117: 191-202.

MONTEIRO S, M CHAPMAN \& A UNDERWOOD (2002) Patches of the ascidian Pyura stolonifera (Heller, 1878): structure of habitat and associated intertidal assemblages. Journal of Experimental Marine Biology and Ecology 270: 171-189.
MYERS A \& T SOUTHGATE (1980) Artificial substrates as a means of monitoring rocky shore cryptofauna. Journal of the Marine Biological Association of the United Kingdom 60: 963-975.

NAVARRETE S \& J CASTILLA (1988) Foraging activities of Chilean intertidal crabs Acanthocyclus gayi Milne-Edwards et Lucas and Acanthocyclus hassleri Rathbun. Journal of Experimental Marine Biology and Ecology 118: 115-136.

OLABARRIA C, A UNDERWOOD \& M CHAPMAN (2002) Appropriate experimental design to evaluate preferences for microhabitat: an example of preferences by species of microgastropods. Oecologia 132: 159-166.

PAINE R (1969) A note on trophic complexity and community stability. American Naturalist 103: 91-93

PAINE R (1974) Intertidal community structure. Experimental studies on the relationship between a dominant competidor and its principal predator. Oecologia 15: 93-120.

PIELOU E (1975) Ecological diversity. Wiley, New York, New York, USA. 165 pp.

PRADO L \& J CASTILLA (2006) The bioengineer Perumytilus purpuratus (Mollusca: Bivalvia) in central Chile: biodiversity, habitat structural complexity and environmental heterogeneity. Journal of the Marine Biological Association of the United Kingdom 86: 417-421.

SANTELICES B (1989). Algas marinas de Chile: distribución, ecología, utilización y diversidad. Ediciones Universidad Católica de Chile, Santiago, Chile. 399 pp.

SCHIEL D \& D TAYLOR (1999) Effects of trampling on a rocky intertidal algal assemblage in southern New Zealand. Journal of Experimental Marine Biology and Ecology 235: 213-235.

SEED R (1996) Patterns of biodiversity in the macroinvertebrate fauna associated with mussel patches on rocky shores. Journal of the Marine Biological Association of the United Kingdom 76: 203-210.

SUCHANEK T (1980) Diversity in natural and artificial mussel bed communities. American Zoologist 20: 807.

SUCHANEK $\mathrm{T}$ (1985) Mussels and their role in structuring rocky shore communities. Ecology of Rocky Coasts volume?: 70-96.

SUCHANEK T (1994) Temperate coastal marine communities: biodiversity and threats. American Zoologist 34: 100-114.

SYMS C \& G JONES (2000) Disturbance, habitat structure, and the dynamics of a coral-reef fish community. Ecology 81: 2714-2729.

THOMPSON R, T CROWE \& S HAWKINS (2002) Rocky intertidal communities: past environmental changes, present status and predictions for the next 25 years. Environmental Conservation 29: 168-191.

THOMPSON R, B WILSON, M TOBIN, A HILL \& S HAWKINS (1996) Biologically generated habitat provision and diversity of rocky shore organisms at a hierarchy of spatial scales. Journal of Experimental Marine Biology and Ecology 202: 7384.

TOKESHI M \& L ROMERO (1995) Filling a gap: dynamics of space occupancy on a musseldominated subtropical rocky shore. Marine Ecology Progress Series 119: 167-176.

TSUCHIYA M (1980) Biodeposit production by the mussel Mytilus edulis L. on rocky shores. Journal of Experimental Marine Biology and Ecology 47: 203222 
UNDERWOOD A (1997) Experiments in ecology: their logical design and interpretation using analysis of variance. Cambridge University Press, Cambridge, United Kingdom. 504 pp.

WALKER B (1992) Biodiversity and ecological redundancy. Conservation Biology 6: 18-23.

WIETERS E (2005) Upwelling-control of positive interactions over mesoscale: a new path linking bottom-up and top-down processes. Marine Ecology Progress Series 301: 43-54.

WONG W, J LEVINTON, B TWINING, N FISHER, B KELAHER \& A ALT (2003) Assimilation of rotifer
Brachionus plicatilis by mussels, Mytilus edulis and Perna veridis: a potiential food web link between zooplankton and benthic suspension feeders in the marine system. Marine Ecology Progress Series 253: $175-182$

YACHI S \& M LOREAU (1999) Biodiversity and ecosystem productivity in a fluctuating environment: the insurance hypothesis. Proceedings of the National Academy of Sciences USA 96: $1463-1468$.

YOUNG C (1990) Larval ecology of marine invertebrates: a sesquicentennial history. Ophelia 32: 1-48.

Associate Editor: Patricio Camus

Received August 11, 2006; accepted March 22, 2007 